Manuscript title:

\title{
Emissions of C\&D refuse in landfills: a European case
}

Authors:

\section{Ana López (corresponding author)}

Ph.D. Student

Environmental Engineering Group

Department of Science and Techniques of Water and the Environment University of Cantabria

Avd. Los Castros s/n

Santander, 39005

Cantabria, Spain

lopezan@unican.es

Tel. +34942202285

Fax. +34942201703

\section{Amaya Lobo}

Associate Professor

Environmental Engineering Group

Department of Science and Techniques of Water and the Environment

University of Cantabria

Avd. Los Castros s/n

Santander, 39005

Cantabria, Spain

loboa@unican.es

Tel. +34942202285

Fax. +34942201703 
2 ABSTRACT:

3 A field study was developed in a new landfill for refuse from construction and demolition 4 (C\&D) material recovery plants of small size (4 Ha.) in Europe, with the aim of evaluating the 5 liquid and gas emissions in this type of facility at a large scale. It included characterization of 6 the materials, monitoring leachate and gas quantity and composition. Besides thermometers, 7 piezometers and sampling ports were placed in several points within the waste. This paper 8 presents the data obtained for five years of the landfill life. The materials disposed were 9 mainly made up of wood and concrete, similar to other C\&D debris sites, but the amount of 10 gypsum drywall (below $3 \%$ of the waste) was significantly smaller than other available 11 studies, where percentages above $20 \%$ had been reported. Leachate contained typical C\&D 12 pollutants, such as different inorganic ions and metals, some of which exceeded other values 13 reported in the literature (conductivity, ammonium, lead and arsenic). The small net 14 precipitation in the area and the leachate recirculation into the landfill surface help explain 15 these higher concentrations, thus highlighting the impact of liquid to solid (L/S) ratio on 16 leachate characteristics. In contrast to previous studies, neither odor nuisances nor 17 significant landfill gas over the surface were detected. However, gas samples taken from the 18 landfill inside revealed sulfate reducing and methanogenic activity.

\section{KEY WORDS:}

20 C\&D waste, leachate, landfill gas, recirculation, instrumentation 


\section{$1 \quad$ 1. INTRODUCTION}

2 The construction industry has a large economic and social role in numerous countries.

3 Traditionally, its development entails an increase in the production of construction and

4 demolition (C\&D) waste, with the subsequent loss of resources and environmental impact. In

5 order to avoid these effects, specific standards have been promulgated recently to regulate

6 the generation and management of this waste, promoting recycling and seeking the

7 reduction of the landfilled quantities (i.e. Gobierno de España, 2008). As a result, numerous

8 plants for C\&D recovery have been opened (i.e. in Spain the plants under operation

9 increased from 61 in 2006 to 130 in 2010, according to MMAMRM (2011)).

The refuse from C\&D recovery plants constitutes a particular case of C\&D waste. Several characteristics, such as the particle size or the proportion of materials making up the waste mixture, vary since recyclable fractions are separated from the original stream. Depending on the collected waste materials, organic matter (wood, paper, cardboard and others) can be a significantly great fraction among the rejects. Therefore, biodegradation processes become relevant when this kind of waste is landfilled and thus organic pollution in the leachate and gases can be problematic, like in other types of non hazardous waste landfills.

Several authors have studied the leachability of hazardous compounds from C\&D waste in the last years. Roussat et al. (2008) found that one of the most troublesome components with regard to the leachate generation is wood, particularly treated and painted wood. Jambeck (2004) studied the leachability of Chromated Copper Arsenate (CCA)-treated wood as a single element and in contact with municipal solid waste (MSW) and C\&D waste in lysimeters. The results regarding arsenic were presented in Khan et al. (2006), while those corresponding to the mixture with other C\&D waste were compiled in Jambeck et al. (2008). Dubey et al. (2009) compared the leachate from CCA-treated wood and Alkaline Copper Quaternary (ACQ) treated wood combined with C\&D waste in lysimeters. On the other hand, Wadanambi et al. (2008) analyzed the lead leachability of lead-based paint in MSW and C\&D landfills environments. 
reuse. Delay et al. (2007) performed leaching tests to measure the release of inorganic pollutants in recycled C\&D waste. Jang and Townsend (2001), in turn, analyzed the sulfate and dissolved solids leached from C\&D debris fines. In this area, Musson et al. (2008) developed a method to approach the gypsum content in these fines and Townsend et al (2004) studied their heavy metal leachability. Other authors have studied the influence of CCA-treated wood on the composition of mulch (Mercer and Frostick, 2012; Townsend et al., 2003).

Laboratory studies, like those mentioned above, are essential to gain detailed knowledge about the processes involved in this kind of landfills. However, in order for these results to contribute to the progress of technology, of the landfill engineering in this case, it is also essential to develop and publish data obtained in full scale facilities. Field data can show how experimental observations transfer to reality, where interactions among processes take place that cannot be reproduced in the laboratory. Nonetheless few data have been reported about landfills receiving C\&D refuse, probably because of their recent appearance, associated with C\&D recovery plants. Existing reports about C\&D landfills, with or without a previous recycling facility, focus on characterizing the leachate quality or quantifying the generated sulphidric acid, as main responsible for odor nuisances, which are one of the principal social impacts of these facilities. The Environment Protection Agency of US published in 1995 a comprehensive study about the potential impacts of C\&D waste landfills, including the characterization of waste and leachate in 21 landfills in the US (USEPA, 1995). Melendez (1996) compiled and compared the leachate generated in different C\&D landfills. Townsend et al. (1999), in turn, studied the leachate generated by some of the materials included in this type of waste under saturated and non-saturated conditions, through several experiments in leaching columns. On the other hand, Weber et al. (2002) analyzed the leachate generated in four test cells built in a C\&D debris landfill. These studies highlight the high sulfate and dissolved solid content of leachate, coming fundamentally from the breakdown of gypsum drywall (calcium and sulfate are the predominant ions observed in the leachate). Moreover, these leachates present elevated concentrations of heavy metals 
which, in some cases such as cadmium and lead, could seriously damage human health and the environment (Melendez, 1996).

An important issue in C\&D landfills results from the deposited gypsum. Owing to the biological reduction of sulfate from gypsum, a variety of reduced sulfur compounds (primarily $\mathrm{H}_{2} \mathrm{~S}$ ) is generated in C\&D debris landfills, causing odor problems in many occasions, and possible health concerns (Eun et al., 2007; Lee et al., 2006; Reinhart et al., 2004). Trying to characterize the problem, Lee et al. (2006), published the gas composition of samples taken from the inside, the waste/cover interface and the ambient air in 10 C\&D debris landfills. The most recent reports have focused on the search of cover materials that attenuate the emission of these compounds (Plaza et al., 2007; Sungthong and Reinhart, 2011; Xu et al., 2010).

These studies, the same as those about leachate mentioned above, have all been developed in American landfills. Further information is needed about the emissions of this kind of facilities in other locations, where not only the local but also the waste characteristics may be different.

This paper provides field data from a full-scale C\&D landfill called Corral Serra in Spain (Europe). It presents the results of a five-year-study which included waste, leachate and landfill gas characterization as well as other variables measured in situ. In a first section a general description of the studied landfill and its associated C\&D waste recovery plant is provided. Then, the study approach is described, including the analytical methodology and instrumentation plan. Finally, the obtained results are presented and discussed in contrast to data reported in other cases.

\section{THE STUDIED LANDFILL}

The new landfill of Corral Serra was built in 2005 to hold the residues from several C\&D recovery plants and transfer stations in a Mediterranean region of Europe. The aim of these facilities is to generate recycled aggregate. They receive waste not only from building and civil construction works but also from demolition and building restoration. The typical 
recovery line starts screening, separating and grinding materials with a size bigger than 400 $\mathrm{mm}$. Then, there is a separation of ferric metals and undesired materials materials such as plastics, metals, wood, hazardous materials, paper-cardboard, wires, glass and other materials. Finally, the sorted aggregates are crushed and divided into different sizes

5 (normally considering three fractions: under $8 \mathrm{~mm}$, under $15 \mathrm{~mm}$ and between 8 and 40 $\mathrm{mm}$ ). The rest (except the recovered ferric metal) are sent to a landfill.

7 The studied landfill has a total surface of $140,000 \mathrm{~m}^{2}$, of which $40,900 \mathrm{~m}^{2}$ have been used for C\&D waste disposal. It has a bottom lining system according to Directive 1999/31/EC

9 (CEU, 1999). The leachate collection system consists of a 50-cm-thick layer of gravel placed on a geotextile that protects the bottom liner. A $250 \mathrm{~mm}$ slotted PE collection pipe receives the leachate along the South-North axis of the landfill and conveys it to the collection sump. From the beginning of operations, in March 2006, until July 2009, 303,738 T of C\&D materials were disposed of, including $218,697 \mathrm{~T}$ of waste and 85,041 T of recycled granular material used as intermediate cover. Figure 1 shows the different operation stages. During the first six months, in which $33,342 \mathrm{~T}$ were received, waste was spread in approximately 2.5-m-high layers, without intermediate cover. During the following four months 33,142 T were disposed of, in-2-m layers with 35-cm-intermediate cover. At the end of this stage there was an average waste thickness of $5 \mathrm{~m}$ in Vessel 1 . In the second stage 73,107 T were buried in 1.8-m-high cells with 55-cm-weekly cover during eleven months, up to an average thickness of $14 \mathrm{~m}$ in Vessel 1. At that time the Vessel 1 surface was at the level of the Vessel 2 bottom. Since December 2007 until July 2009 93,040 T of waste were spread in 2.1-m layers with 20-cm-intermediate cover. The final average thickness was $17 \mathrm{~m}$ in Vessel 1 and $6 \mathrm{~m}$ in Vessel 2. Based on topographical data, a global average density (waste and cover) of $0.83 \mathrm{~T} / \mathrm{m}^{3}$ was reached in the landfill; the average apparent density of waste was $0.60 \mathrm{~T} / \mathrm{m}^{3}$. This value is quite higher than the reference range for mixed construction waste [0.18 to $0.36 \mathrm{~T} / \mathrm{m}^{3}$ ], reported by Tchobanoglous et al. (1993). This difference corresponds to the type of waste. The residues received in Corral Serra come from a recovery plant that rejects the smallest 
fractions, which are easier to compact than the conventional C\&D waste mixture.

The yearly net precipitation in the area is negative. Taking advantage of this fact, leachate is stored inside the landfill and in external ponds, from where it is recirculated to promote evaporation by irrigation on the waste when there is no rain.

\section{EXPERIMENTAL STUDY}

\subsection{WORK PLAN}

In order to take advantage of the new landfill as a pilot experiment to characterize the emissions in this kind of facilities located in similar climatic areas in Europe, a study was planned. It included a detailed record of the operational practices, waste, leachate and gas samples characterization, in situ monitoring of several variables (temperature, leachate head on the bottom liner and settlement) and gas/liquid samples extraction from several points inside the waste body. This study was as a part of a Collaboration Research Project between TIRME S.A. and the Environmental Engineering Group of the University of Cantabria (GIAUC), to gain knowledge about processes occurring inside the landfill and help understand the consequences of leachate recirculation, which is not a common practice in this kind of landfills. It supplements the general Environmental Surveying Plan of the landfill, which also considers surface gas analyses by flux chamber method monthly, quarterly analyses of underground water, leachate and runoff water and topographical surveys.

\subsection{INSTRUMENTATION}

An instrumentation plan was designed for monitoring some internal parameters in the landfill (temperature, leachate head on the liner, gas composition and settlement). Considering the control needs, financial constraints and the operation plan, the landfill was divided into several zones, where instrumentation was installed. During the operation period four PT-100 thermoresistences $(T)$, four vibrating wire piezometers model 4500 (Geokon) (PZ), two of them with temperature reading, six gas/liquid sampling ports (SP) and 2 settlement plates were installed. The sampling ports are handmade devices based on Zhao et al. (2003), consisting of a slotted stretch of PVC pipe connected to the exterior through 15-mm PVC 
hoses, from which gas or liquid samples, depending on what is accumulated in the corresponding point, are pumped. In Vessel 1, PZ 1-1 and PZ 2-1 were placed at an elevation of $36.3 \mathrm{~m}, \mathrm{~T} 1-2$ and T2-2 at $42.5 \mathrm{~m}$ and T1-3 and T2-3 at $50 \mathrm{~m}$. Besides, four sampling ports were installed in the same landfill vessel (SP1-2 and SP2-2 at a height of 6.5 $\mathrm{m}$ and SP 1-3 and SP 2-3 at $14 \mathrm{~m}$ from the bottom) and two in Vessel 2 (SP3-1 and SP4-1 at $0.5 \mathrm{~m}$ from the bottom) (Figure 1).

Piezometers and thermometers are manually read (via GEOKON GK-404 model and ISOTECH IDM 91E digital multimeter, respectively) every week. On the other hand, a portable gas measurement device (GA 2000, Geotechnical Instruments) is used for the analyses of gas samples taken from the sampling ports installed within the waste. The detection limits of the equipment are $0-100 \%$ for $\mathrm{CH}_{4}$ and $\mathrm{CO}_{2}, 0-25 \%$ for $\mathrm{O}_{2}$ and $0-500$ ppm for $\mathrm{H}_{2} \mathrm{~S}$ and $\mathrm{CO}$. Every six months a vacuum pump (Millipore XX5522050) is connected to the hoses to obtain the samples of the gas/liquid in contact with the waste. After a first suction period of $10 \mathrm{~min}$, if no liquid is obtained, the pump exit is connected to the GA2000 meter, with which the gas is suctioned for $60 \mathrm{~s}$ and analyzed. The measurement with the portable analyzer is repeated for $30 \mathrm{~s}$. Then the pumping is started for five minutes and connected to the GA2000 again. The four measurements obtained as a result are compared and, if they are stable, averaged to give the final value. Otherwise the suction time is increased, until a steady reading is obtained.

Two settlement plates were placed on Vessel 1, but they had to be eventually removed due to operational interferences in the active area.

\subsection{PERFORMED ANALYSES}

Five characterization campaigns were performed since the landfill opening to determine the material composition of the waste incoming from each origin (a total of 8 plants). The campaigns took place in June 2007, November 2007, June 2008, November 2008 and June 2009.

From June 2007, leachate samples taken from the collecting sump and gas collected from the sampling devices inside the waste have been analyzed with different frequencies in each 
operation stage. Leachate analyses were initially performed on a monthly basis, every two months later and half-yearly after the end of operation in July 2009. They include $\mathrm{pH}$, dissolved oxygen (DO), conductivity, redox potential (ORP), dissolved and total chemical oxygen demand (COD), dissolved and total biochemical oxygen demand $\left(\mathrm{BOD}_{5}\right)$, total organic carbon (TOC), total nitrogen (TN), ammonia nitrogen $\left(\mathrm{NH}_{4}-\mathrm{N}\right)$, alkalinity, sulphates, total solids (TS), total volatile solids (TVS), total suspended solids (TSS) and volatile suspended solids (VSS), and heavy metal concentrations. All the analyses are performed according to standardized methods (Eaton et al., 2005). For metal concentrations, in particular, leachate samples were preserved with concentrated acid nitric $\left(\mathrm{HNO}_{3}\right)(\mathrm{pH}<2)$. Then, they were digested according to the Standard Method 3030E and filtered afterwards with a $0.45 \mu \mathrm{m}$ filter in order to be analyzed in an atomic absorption spectrometer (Perkin Elmer 300 AAnalyst Spectrometer).

\section{RESULTS}

\subsection{WASTE CHARACTERIZATION}

The waste received in the landfill was recorded distinguishing the quantities coming from different sources. Considering that record and also the results of the different characterization campaigns, the composition of the waste disposed in Corral Serra was obtained (Table 1).

As it is shown, slowly (wood, textiles) and readily (paper and cardboard) biodegradable materials represent a great fraction of the refuse stream. The significant contribution of wood, in particular, $31 \%$ of the total disposed material, coincides with the amount received in other C\&D landfills (USEPA, 1995). In fact, great part of the experimental studies on the pollution potential of C\&D waste, some of them mentioned above, focus on characterizing the leachability of wood treated in different ways (Dubey et al., 2009; Jambeck et al., 2008; Khan et al., 2006). Wood, in this case, comes mainly from furniture collected in the transfer stations and demolition of buildings where it is used in some elements (windows and shutters, doors, floors and, rarely, in structures). Its high presence in the landfill is due to the 
fact that nowadays it is not recovered in recovery facilities.

Apart from that, the small quantity of gypsum identified in this case $(0.1 \% \mathrm{w} / \mathrm{w})$ is remarkable. It coincides with the range reported for this kind of waste in Europe, between 0.1 and $0.4 \%(E U, 2011)$. However, the actual fraction of this material may be greater, if we consider the gypsum contained in the fines. According to the operator company the average fraction of gypsum in the fines recovered in the Material Recovery Facilities (MRFs) in the area is $3.6 \%$. On the other hand, Musson et al. (2008) the gypsum represents between 1 and $25 \%$ of the fines generated in different industries in the US. Assuming that the fines in this study included $25 \%$ of gypsum, the percentage of this material in the landfill studied in this case would be $3.7 \%$, still very limited compared to data stated in other countries. USEPA (1998) reports a range from 21 to $27 \%$ of gypsum drywall in the C\&D waste received in American landfills. This great difference is caused by the specific construction customs in each region. Bricks are usually used to partition off buildings in the South of Europe and not gypsum drywall. The only gypsum building elements commonly used in those countries are plaster ceilings and plaster mouldings.

\subsection{LEACHATE VOLUME AND COMPOSITION}

\subsubsection{Leachate volume}

During the 66 months of study, $1221 \mathrm{~mm}$ (an average of $18 \mathrm{~mm} / \mathrm{month}$ ) of net precipitation (direct precipitation on the landfill surface minus potential evaporation, on a monthly balance) were received. Figure 2 shows the rainfall intensity in the landfill and the collected leachate during the months studied. As it is expected in a small landfill with important preferential pathways, the response to rain is fast. The delay between rainfall and collected leachate that appears in the graphic is mainly due to the way in which it was managed, with temporary water storage inside the landfill. During the study period, leachate was being collected from the landfill discontinuously, to recirculate it directly on the waste or to store it in a regulation pool (for subsequent recirculation). 
Until August 2011, $393 \mathrm{~mm}$ of leachate ( $6 \mathrm{~mm} / \mathrm{month}$ on average) were collected (a total of $\left.16,057 \mathrm{~m}^{3}\right)$. It means $13 \%$ of the rainfall registered throughout the time $(2,925 \mathrm{~mm})$, that is, a very low value especially taking into account the leachate recirculation. As a reference, Stegmann and Ehrig (1989) estimated an annual average ratio of leachate/rainfall of $18 \%$ in a study of several landfills in Germany, operating without leachate recirculation. Bearing in mind the quantity of waste disposed during the operation, it leads to a global average L/S ratio of $53 \mathrm{~L} / \mathrm{T}$ during those months $\left(16,057 \mathrm{~m}^{3}\right.$ over $\left.303,738 \mathrm{~T}\right)$, quite low when compared to other values reported in studies of C\&D waste. For example, Weber et al. (2002) added between 2,800 and $4,400 \mathrm{~L}$ of rainfall per $\mathrm{T}$ of waste during six months of experiment to characterize the leachate from four test cells filled with residential construction waste. On the other hand, Delay et al. (2007) achieved a L/S ratio of about 600 L/T after 400 days in their column leaching test to determine the quantity of inorganic contaminants released in that kind of waste.

\subsubsection{Leachate composition}

Table 2 shows the maximum, minimum and average values obtained in the leachate analyses during this period compared to other data reported in the literature for C\&D landfill leachate. The average values observed are generally higher than the reference average values compiled by Melendez (1996), as befits a dry landfill like Corral Serra. A classic leaching curve for inorganic elements such as those presented by Delay et al. (2006) for demolition waste, shows a front where leachate concentrations remain in the maximum values, given by the solubility of each element, during the first stages of the experiment. After a minimum L/S ratio (above $0.1 \mathrm{~L} / \mathrm{kg}$, depending on the element studied) concentrations begin to decrease as more water is added, reflecting the washing-off effect. The ratio achieved in this study $(0.053 \mathrm{~L} / \mathrm{kg})$ is well under the typical minimum, what shows that high concentrations observed correspond to the front of the leaching curve and will decrease in future as water washes the waste.

Besides, the leachate recirculation carried out since June 2007 favors evaporation of water and therefore the reduction of the volume to manage and, consequently, the increase of its 
concentration. Furthermore, recirculation raises the moisture content of waste and improves the distribution of water and its nutrients. This facilitates waste degradation, both by physicochemical and biological phenomena, and thus the solution of pollutants into the leachate. As a result, in this case some samples exceed the maximum reference concentrations in some parameters: conductivity, ammonia nitrogen, arsenic and lead. As in other places, the $\mathrm{pH}$ values maintained in the neutral-basic range (between 7.4 and 8.3). This matches the high alkalinity (an average of approximately $3,200 \mathrm{mg} \mathrm{CaCO}_{3} / \mathrm{L}$ ) due mostly to dissolution of carbonates from concrete and disposed aggregates. The average conductivity registered in this study $(8.3 \mathrm{mS} / \mathrm{cm})$ is five times higher than the average found in bibliography. It matches the total dissolved solids (TDS) concentrations found in this leachate which, although they do not go beyond the reference range $(990-8,400 \mathrm{mg} / \mathrm{L}$ in Melendez (1996)), their average $(4,860 \mathrm{mg} / \mathrm{L})$ is twice the average values reported. Conductivity and TDS are related to the quantity of dissolved ions. In this leachate the largest ions are alkalinity, sodium, calcium and sulfates. The first three of them appear in higher concentrations than those found in literature. The high concentrations of sulfates are specially striking in this case, being the quantity of gypsum smaller than in other studies; they are a consequence of the limited L/s ratio mentioned above together with the high and fast solubility of gypsum (see Musson et al., 2008).

Conductivity, sodium and sulfates measured in the leachate samples are shown in Figure 3A. The temporary effect of dilution caused by rainfall, which reduces leachate concentration in October 2007, May and December 2008 and October 2009, for instance, is seen. Taking into consideration the great variability depending on rainfall, an increasing trend throughout the study period can also be noticed. That slight trend, an effect of the leachate concentration by recirculation, is also observed in sulfate and sodium concentrations. Figure 3B shows the $\mathrm{COD}$ and $\mathrm{NH}_{4} \mathrm{~N}$ evolution over time. In comparison with other parameters, these ones do not indicate a clear trend; they keep values in a similar range for the whole period. In the case of COD, its trend to increase may be made up for by the transformation of biodegradable compounds into gas. These phenomena are discussed in 
the paragraphs below.

COD concentrations within the published range have been registered but, once again, with higher average concentrations. Among C\&D waste, the materials which cause the most organic pollution are: cardboard, insulation materials and wood (Townsend et al., 2000). In the case studied, these components represent more than $36 \%$ of the disposed material. However, because of the type of waste, the organic pollution is essentially nonbiodegradable: the BOD/COD relation has fluctuated between 0.044 and 0.205.

Compared to other authors, $\mathrm{NH}_{4} \_\mathrm{N}$ average concentration $(400 \mathrm{mg} / \mathrm{L})$ stands out, thus they are significantly higher (more than 10 times) than the average reported value. Since the source of $\mathrm{NH}_{4} \mathrm{~N}$ is the decomposition of organic waste, these high concentrations can be associated to the amounts of wood and cardboard disposed of, to the enhanced decomposition of the waste and, above all, to the limited dilution of the leachate in this case. On the other hand, part of the $\mathrm{NH}_{4}-\mathrm{N}$ which appears in the leachate volatilizes in the form of free ammonia. The rate of free ammonia in the leachate depends on $\mathrm{pH}$ and temperature. Ritzkowski and Stegmann (2003) found in an aerobic bioreactor that with a pH 7.4 and at $35^{\circ} \mathrm{C}$, the $50 \%$ of ammonia nitrogen initially present in the leachate was volatilized. Thus, the quantity of $\mathrm{NH}_{4} \_\mathrm{N}$ volatilized can be important in the conditions of the landfill studied (moderately basic $\mathrm{pH}$ and average temperatures between 30 and $51^{\circ} \mathrm{C}$ ), especially in the recirculation by superficial spraying. In fact, a smell of ammonia is perceived during leachate recirculation around the recirculating truck. Moreover, when waste samples have been extracted by means of drilling or excavation that smell has also been detected, sign of the volatilization of the compound in the environment. This explains why its concentration in leachate has not increased during these years of operation.

On the other hand, as it is usual in this kind of landfills, several heavy metals were consistently detected in the leachate. Due to the methodology used, the measured concentrations include the particulate fraction of metals present in the samples, which were digested before the filtration. Because of that some values exceed the solubility corresponding to the $\mathrm{pH}$ detected, as it happens in other studies. $\mathrm{Pb}$ and As stand out 

among them. Both the range and the average of arsenic concentrations obtained in the leachate exceed the typical values found in C\&D landfills. Chromium is within the range, but with higher average concentrations, while copper is in a lower range. These three elements, in various chemicals forms, are used to preserve wood (Melendez, 1996). It is the case of

5 CCA treated wood, preserved with chromic acid, copper oxide and arsenic acid (USDA 1980) to which Weber et al. (2002) attribute most of $\mathrm{As}$, $\mathrm{Cu}$ and $\mathrm{Cr}$ found in landfill. As well as the case of ACQ-treated wood, preserved with alkaline copper quaternary, whose main ingredient is copper (Dubey et al., 2009). Higher arsenic concentrations, than those obtained in this study (48 - $724 \mu \mathrm{g} \mathrm{As/L),} \mathrm{were} \mathrm{found} \mathrm{in} \mathrm{specific} \mathrm{studies} \mathrm{about} \mathrm{leachability} \mathrm{of} \mathrm{treated}$ wood. Dubey et al. (2009) used 5\% by weight of CCA-treated wood in the analyzed waste and measured As concentrations from 500 to $1,200 \mu \mathrm{g} / \mathrm{L}$, while Jambeck et al. (2008) used 10.2\% CCA-treated wood and measured concentrations ranging from 1,090 to $4,250 \mu \mathrm{g} / \mathrm{L}$ (with a L/S range of $1560 \mathrm{~L} / \mathrm{T}$, quite higher than the present study). However, Jang and Townsend (2003) (0.5\% CCA-treated wood) measured lower concentrations (10 - $380 \mu \mathrm{g} / \mathrm{L})$. On the other hand, $\mathrm{Cr}$ concentrations measured in this leachate range from 5 to $250 \mu \mathrm{g} / \mathrm{L}$. These values are similar to those obtained by Jang and Townsend (2003) $(71.9-165 \mu \mathrm{g} / \mathrm{L})$ and by Dubey et al. (2009) (75 to $200 \mu \mathrm{g} / \mathrm{L}$ ), but lower than the ones obtained by Jambeck et al. (2008) (300 to $2,100 \mu \mathrm{g} / \mathrm{L})$.

In this case, with regard to the studies of reference, the lower presence of Cu may be due to its combination with reduced sulfur compounds forming very insoluble precipitates which remain in the waste within the landfill (Dubey et al., 2009; Jambeck et al., 2008; Weber et al., 2002). This combination and other ones of different elements are promoted by recirculation, which increases the retention time of these compounds and improves their mixture in the whole landfill. In the case of lead, both the range and the average obtained in this study have been higher than concentrations found in literature, although only on six occasions (of 31 measurements) have exceeded 1,500 $\mu \mathrm{g} / \mathrm{L}$. The main sources of lead in C\&D waste are paints and coating 
is an additive and is also used in flashing (Melendez, 1996).

Figure $3 \mathrm{C}$ shows the evolution of $\mathrm{As}, \mathrm{Cr}, \mathrm{Cu}$ and $\mathrm{Pb}$ concentrations in the leachate. As it is presented, $\mathrm{As}, \mathrm{Cu}$ and $\mathrm{Pb}$ concentrations have decreased during these months. This drop may be connected with the evolution of the redox potential (ORP) which has changed from values lower than $-300 \mathrm{mV}$ in the second year of monitoring to values higher than $350 \mathrm{mV}$ at the end of the study. In the case of As, for example, its mobility drops at a constant pH with higher ORP values and as a result, the amount of leached arsenic decreases (Moghaddam and Mulligan, 2008).

\subsection{INSTRUMENTATION}

\subsubsection{Gas composition}

No odor nuisances, typical of these C\&D landfills (i.e. Lee et al. (2006) reported ambient concentrations up to $50 \mathrm{ppmv}$ ), have been reported by the closest residents and landfill workers in Corral Serra. In fact, considerable concentrations of landfill gases were not detected in the air quality monitoring campaigns within the landfill boundaries. Likewise, no significant surface emissions were measured through the dynamic flux chamber method with latter gas chromatography (GC) analyses (CEN EN 13725, 2003): $\mathrm{CH}_{4}$ and $\mathrm{H}_{2} \mathrm{~S}$ remained under detection limits, of $10 \mathrm{ppm}$ and 0.001 ppmv respectively, and $\mathrm{CO}_{2}$ concentrations between 0.04 and $0.14 \%$ were measured.

However, analyses of gas collected from the sampling ports installed inside the waste allowed detecting a certain anaerobic activity in the landfill, in keeping with the leachate characteristics and its high retention time, which favors decomposition of dissolved pollutants. Figure 4 presents the evolution of $\mathrm{CH}_{4}$ and $\mathrm{H}_{2} \mathrm{~S}$ concentrations registered in the sampling ports 1-2, 1-3 and 4-1 over time: in order not to make the graph difficult to interpret these points have been chosen as representative of the different layers where instrumentation inside the landfill has been placed. As it is shown, maximum concentrations of $50 \%$ of $\mathrm{CH}_{4}$ and above 500 ppmv of $\mathrm{H}_{2} \mathrm{~S}$ were reached in these internal points of the landfill. Following methane concentrations, how the degradation processes developed in 
several areas of the landfill can be estimated.

Methane concentration increased quickly in the intermediate layers of Vessel 1 (represented by the point SP 1-2), since the installation of the sampling ports. In March 2008 this concentration started decreasing. At that moment there were already more than $10 \mathrm{~m}$ of waste over the sampling ports which made the flow of water through the area difficult. This, along with the existing high temperature (around $50^{\circ} \mathrm{C}$ according to the monitoring data), dried the waste in the area.

In contrast, in Vessel 2 (point 4-1) the methane rises more slightly as the waste is covered. This SP is buried near the bottom of the vessel and thus it does not receive contributions of gas coming from older waste located beneath it, such as the case of SP1-2, mentioned above.

The latter sampling ports placed (SP 1-3) stayed two meters below the final level reached in area 1, leaving $14 \mathrm{~m}$ of waste below. They quickly detected significant concentrations of landfill gas; at first, most of it came from the lower layers and then, they were almost certainly generated in the area, which remained moist thanks to the surface water contribution.

These results were obtained sucking previously the hoses for ten minutes, as it has been explained in the section on methodology. On the whole, stable measurements were not achieved when the length of suction was shorter. This means that the pressure of biogas (and therefore, its generation) on the inside is limited. This is also revealed in the measurements registered in January 2010, which correspond to a period of great intensity of leachate recirculation which caused a marked drop in temperatures (Figure 5) and displaced the gas generated in the waste pores, reducing sharply the measured concentrations. This limited pressure, together with the use of intermediate cover layers during the operation, explains the lack of significant emissions through the surface.

As for hydrogen sulphide, it shows a different trend, common in all the points. The highest concentrations were observed in the beginning owing to sulfate degradation (previous to the implementation of the methanogenic phase). In other similar landfills soil vapor 
concentrations have been measured up to 12,000 ppmv (Lee et al., 2006). However, in this case the smaller drywall presence in waste makes $\mathrm{SO}_{4}{ }^{2-}$ availability more limited and thus the production of $\mathrm{H}_{2} \mathrm{~S}$ by sulfate reducing bacteria is lesser. Besides, there are other phenomena that reduce $\mathrm{H}_{2} \mathrm{~S}$ concentrations in air, such as cover soil attenuation, air dilution, its sorption to concrete surfaces (Plaza et al., 2007) or its solution into the leachate (Reinhart et al., 2004). In any case, during the first stages of operation, in 2006, there was a significant concentration of hydrogen sulphide in leachate: yellow precipitates were formed in the leachate collection sump, which probably originated from spontaneous sulphide oxidation to sulfur when the leachate came out the landfill to an oxic ambient. This is effect of the little dilution that causes, despite the limited presence of sulphated elements in the waste, leachate to show high concentrations of these compounds.

\subsubsection{Temperatures}

Figure 5 shows the evolution of the temperature lectures in three of the installed PT100, in contrast to the ambient temperature in the landfill. As in the case of sampling ports, these sensors have been chosen as representative of each landfill area in order to simplify the graph and make its interpretation easier.

Thermocouples 1-2 and 2-2 were the first ones placed inside the waste, $6.5 \mathrm{~m}$ from the bottom of Vessel 1. During the operation $7.5 \mathrm{~m}$ of waste were placed over them. A rapid rise in the temperature, from over $30^{\circ} \mathrm{C}$ up to the thermophilic range $\left(50-60^{\circ} \mathrm{C}\right)$, took place during the first months after the sensors installation. These high temperatures indicate a release of thermal energy as a result of waste degradation and coincide with the maximum data obtained in other landfills (i.e. Yeşiller et al. (2005)). After that, temperatures started decreasing until they reached values around $42^{\circ} \mathrm{C}$ at the end of the study, that is, in the appropriate range for methane generation (Rees, 1980).

Thermocouple 1-3, placed in the same area but $14 \mathrm{~m}$ from the bottom, registered a similar initial increase (from 49 to $57^{\circ} \mathrm{C}$ in the first months) which dropped immediately when it started to rain in the fall of 2009. From that moment it developed in parallel with the ambient temperature. It is important to take into account that this sensor, along with the 2-3 one, had 
less than $2 \mathrm{~m}$ of waste above, unlike 1-2 and 2-2.

The evolution of temperatures at point $4-1$, in turn, is much smoother. It was located on the bottom of Vessel 2, isolated from the outside by an up to 5.5-m-thick layer of waste. It is also in contact with the water which percolates through the waste and goes to the leachate extraction pipe. An increasing trend in time is observed, which matches an active waste degradation.

\subsubsection{Piezometers}

During the 41 months water storage was constantly registered only in PZ 1-1, which is located at the lowest level $(36.3 \mathrm{~m})$ of the four piezometers of control. In this point readings began increasing continuously from July 2009, in keeping with the strategies of leachate storage within the waste. Since then, they stayed on average values of $36.9 \mathrm{~m}$, revealing water storage on the bottom of approximately $60 \mathrm{~cm}$. As a consequence of rainfall, isolated positive readings (some weeks) were registered both at this point and at the other piezometers during operation. These monitoring data of water storage at the bottom were used to control the strategy of leachate management and to check the correct operation of the drainage system.

\section{CONCLUSIONS}

In spite of its origin, which is a specific facility for C\&D waste recovery, the materials disposed in the studied case are similar to other C\&D debris sites, mainly made up of wood and concrete. Nonetheless, the amount of gypsum drywall is significantly smaller than the reported in the available American studies. This makes the behavior of the landfill different, as it will be in other sites, depending on the composition of the waste. A significant difference is that no odor nuisances are expected in these cases, even though landfill gas can be generated through biological degradation of organic waste.

The amount of water received in the landfill is significantly smaller than in other cases reported, due to the scant precipitation and large evaporation potential in the area. As a result, the generated leachate volume is considerably limited. This supports the strategy 
adopted for the leachate management in cases like this one, that is, with internal storage in the landfill or external one in the pond and recirculation when it does not rain.

In regard to the liquid emissions, an outstanding presence of dissolved salts and metals, as observed in other cases, has been measured. The recirculation and the great evaporation make the leachate to be quite concentrated. Because of that, some parameters in this study exceed the ranges reported in the literature, showing the key influence of the liquid to solid ratio to which waste has been subject. Such is the case of conductivity, ammonia nitrogen, lead and arsenic. It must also be noticed that recirculation facilitates waste degradation when its moisture increases although in this case in a very limited way. This effect also supports the approach adopted for a more sustainable operation.

\section{ACKNOWLEDGEMENTS}

This research project is financed by TIRME S.A. The cooperation and active participation of personnel at the landfill is acknowledged gratefully.

\section{REFERENCES}

CEN EN 13725. 2003. Air Quality - Determination of Odour Concentration by Dynamic Olfactometry. Brussels.

Delay, M., Lager, T., Schulz, H.D., Frimmel, F.H., 2007. Comparison of leaching test to determine and quantify the release of inorganic contaminants in demolition waste. Waste Manage. 27, 248-255.

CEU (The Council of the European Union), 1999. Directive 1999/31/EC, of 26 April 1999, on the landfill of waste. Official Journal of the European Communities, 1999.

Dubey, B., Spalvins, E., Townsend, T.G., Solo-Gabriele, H.M., 2009. Comparison of metals leaching from CCA- and ACQ-treated wood in simulated construction and demolition debris landfills. J. Environ. Eng. 135, 910-917.

Eaton, A.D., Clesceri, L.S., Rice, W.E., Greenberg, A.E., 2005. Standard Methods for the 
Examination of Water and Wastewater. 21st ed. APHA, AWWA, WPCF, Washington, D.C.

EC (European Commission), 2011. Service Contract on Management of Construction and Demolition Waste -SR1. ENV.G.4/FRA/2008/0112. Final Report. Paris.

Eun, S., Reinhart, D., Cooper, D., Townsend, T., Faour, A., 2007. Hydrogen sulphide flux measurements from construction and demolition debris (C\&D) landfills. Waste Manage. $27,220-227$.

Gobierno de España, 2008. Real Decreto 105/2008. de 1 de Febrero, por el que se regula la producción y gestión de los residuos de construcción y demolición (in Spanish).

Jambeck, J.R., 2004. The Disposal of CCA-Treated Wood in Simulated Landfills: Potential Impacts. PhD Dissertation, University of Florida, Gainesville, FL.

Jambeck, J., Townsend, T.G., Solo-Gabriele, H.M., 2008. Landfill disposal of CCA-treated wood with construction and demolition (C\&D) debris: arsenic, chromium, and copper concentrations in leachate. Environ. Sci. Technol. 42, 5740-5745.

Jang, Y.C., Townsend, T., 2001. Sulfate leaching from recovered construction and demolition debris fines. Adv. Environ. Res. 5, 203-217.

Jang, Y., Townsend, T., 2003. Effect of waste depth on leachate quality from laboratory construction and demolition debris landfills. J. Environ. Eng. Sci. 20,183-196.

Khan, B.I., Jambeck, J., Solo-Gabriele, H.M., Townsend, T.G., Cai, Y., 2006. Release of arsenic to the environment from CAA-treated wood. 2. Leaching and speciation during disposal. Environ. Sci. Technol. 40, 994-999.

Lee, S., Xu, Z., Booth, M., Townsend, T., Chadik, P., Bitton, G., 2006. Reduced sulfur compounds in gas from construction and demolition debris landfills. Waste Manage. 26 $526-533$.

Melendez, B., 1996. A Study of Leachate Generated from Construction and Demolition Waste Landfills. MS Dissertation, University of Florida, Gainesville, FL.

Mercer, T.G., Frostick, L.E., 2012. Leaching characteristics of CCA-treated wood waste: a UK study. Sci. Total Environ. 427-428, 165-174. 
MMAMRM (Ministerio de Medio Ambiente y Medio Rural y Marino), 2011. El medio ambiente y el medio rural y marino en España 2010. Madrid.

Moghaddam, A.H., Mulligan, C.N., 2008. Leaching heavy metals from chromate copper arsenate (CCA) treated woof after disposal. Waste Manage. 28, 628-637.

Musson, S.E., Xu, Q., Townsend, T.G., 2008. Measuring the gypsum content of C\&D debris fines. Waste Manage. 28, 2091-2096.

Plaza, C., Xu, Q., Townsend, T., Bitton, G., Booth, M., 2007. Evaluation of alternative cover soils for attenuating hydrogen sulfide from construction and demolition (C\&D) debris landfills. J. Environ. Manage. 84, 314-322.

Rees, J.F., 1980. Optimisation of methane production and refuse decomposition in landfills by temperature control. J. Chem. Technol. Biotechnol. 30, 458-465.

Reinhart, D., Townsend, T., Eun, S., Xu, Q., 2004. Control of Odors in Construction and Demolition (C\&D) Debris Landfills. Florida Center for Solid and Hazardous Waste Management.

Ritzkowski, M., Stegmann, R., 2003. Emission behavior of aerated landfills: results of laboratory scale investigations. In: Proceedings Sardinia 2003, Ninth International Waste Management and Landfill Symposium, S. Margherita di Pula, Cagliari, Italy.

Roussat, N., Méhu, J., Abdelghafour, M., Brula, P., 2008. Leaching behavior of hazardous demolition waste. Waste Manage. 28, 2032-2040.

Stegmann, R., Ehrig, H.J., 1989. Leachate production and quality - results of landfill processes and operation. In: Proceedings Sardinia 1989, Second International Landfill Symposium, S. Margherita di Pula, Cagliari, Italy.

Sungthong, D., Reinhart, D.R., 2011. Control of hydrogen sulfide emissions using autotrophic denitrification landfill biocovers: engineering applications. Front. Environ. Sci. and Eng. China 5, 149-158.

Tchobanoglous, G., Theisen, H., Vigil, S.A., 1993. Integrated Solid Waste Management, International Edition. McGraw-Hill; 1993.

Townsend, T.G., Jang, Y., Thurn, L.G., 1999. Simulation of construction and demolition 
waste leachate. J. Environ. Eng. 125, 1071-1081.

Townsend, T.G., Jang, Y., Weber, W., 2000. Continued research into the characteristics of leachate from construction and demolition waste landfills. Florida Center for Solid and Hazardous Waste Management.

Townsend, T.G., Solo-Gabriele, H., Tolaymat, T., Stook, K., 2003. Impact of chromate copper arsenate (CCA) in wood mulch. Sci. Total Environ. 309, 173-185.

Townsend, T., Tolaymat, T., Leo, K., Jambeck, J., 2004. Heavy metals in recovered fines from construction and demolition debris recycling facilities in Florida. Sci. Total Environ. $332,1-11$.

USDA, 1980. The biological and economic assessment of pentachlorophenol, inorganic arsenicals, creosote. Volume I: Wood preservatives. Technical Bulletin №. 1658-1. Washington, DC.

USEPA, 1995. Construction and demolition waste landfills. Report No. 68-W3-0008. Washington, DC.

USEPA, 1998. Characterization of building-related construction and demolition debris in the United States. Report No. 530-R98-010. Washington, DC.

Wadanambi, L., Dubey, B., Townsend, T., 2008. The leaching of lead from lead-based paint in landfill environments. J. Hazard. Mater. 157, 194-200.

Wang, Y., Sikora, S., Kim, H., Dubey, B., Townsend, T., 2012. Mobilization of iron and arsenic from soil by construction and demolition debris landfill leachate. Waste Manage. $32,925-932$.

Weber, W., Jang, Y., Townsend, T., Laux, S., 2002. Leachate from land disposed residential construction waste. J. Environ. Eng. 128, 237-245.

Xu, Q., Townsend, T., Reinhart, D., 2010. Attenuation of hydrogen sulfide at construction and demolition debris landfills using alternative cover materials. Waste Manage. 30, 660666.

Yeşiller, N., Hanson, J.L., Lium W.L., 2005. Heat generation in municipal solid waste landfills. J. Geotech. Geoenviron. Eng. 131, 1330-1344. 
1 Zhao, X., Voice, T., Khire, M., Maher, S., Musleh, R., Hweerwani, P., Hashsham, S., 2003.

Full scale evaluation of bioreactor landfill technology. In: Proceedings Eighth Annual

$3 \quad$ Landfill Symposium, Atlantic City, EEUU. 

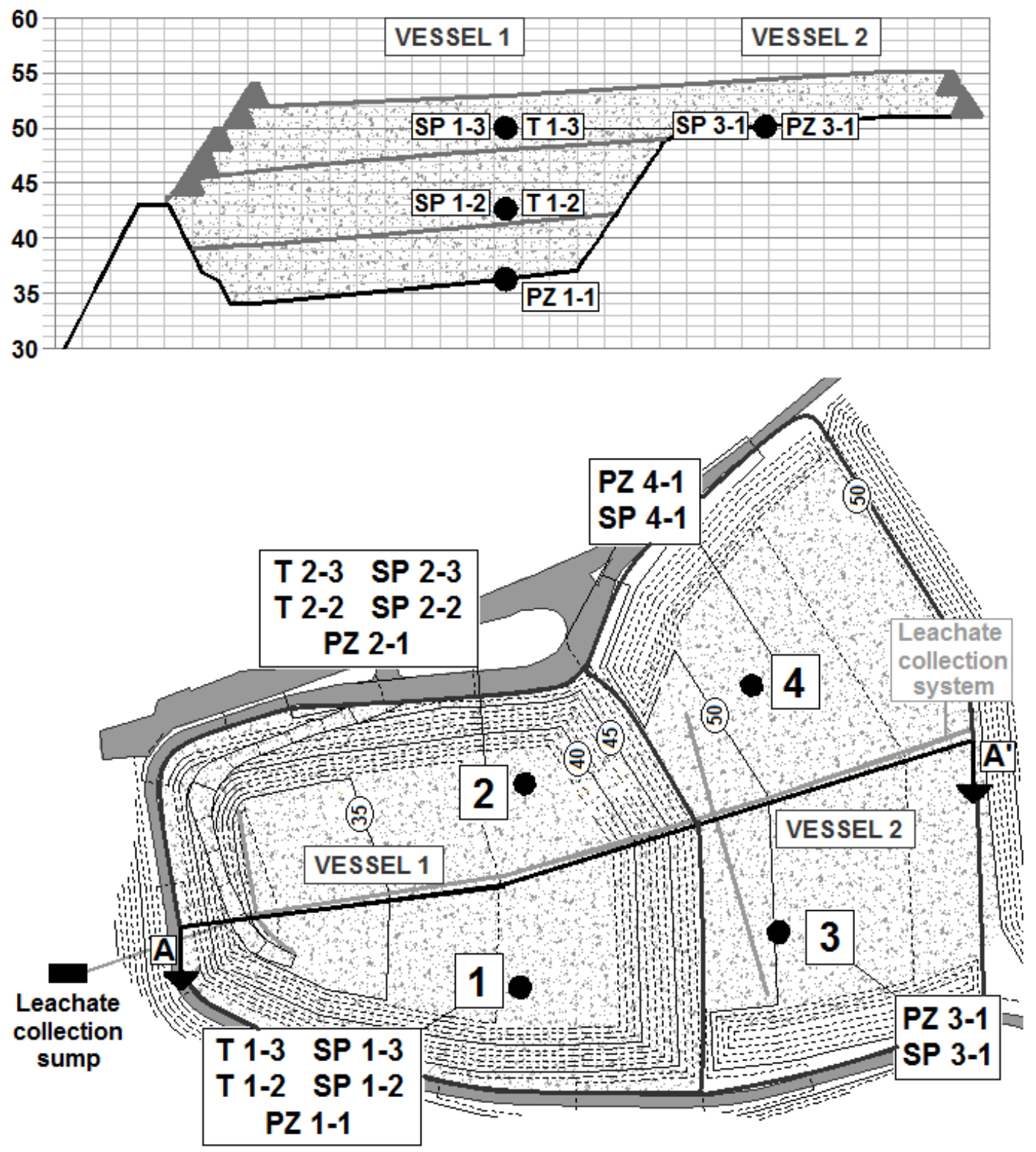

Figure 1. Studied landfill: layout, operation phases and instrumentation 


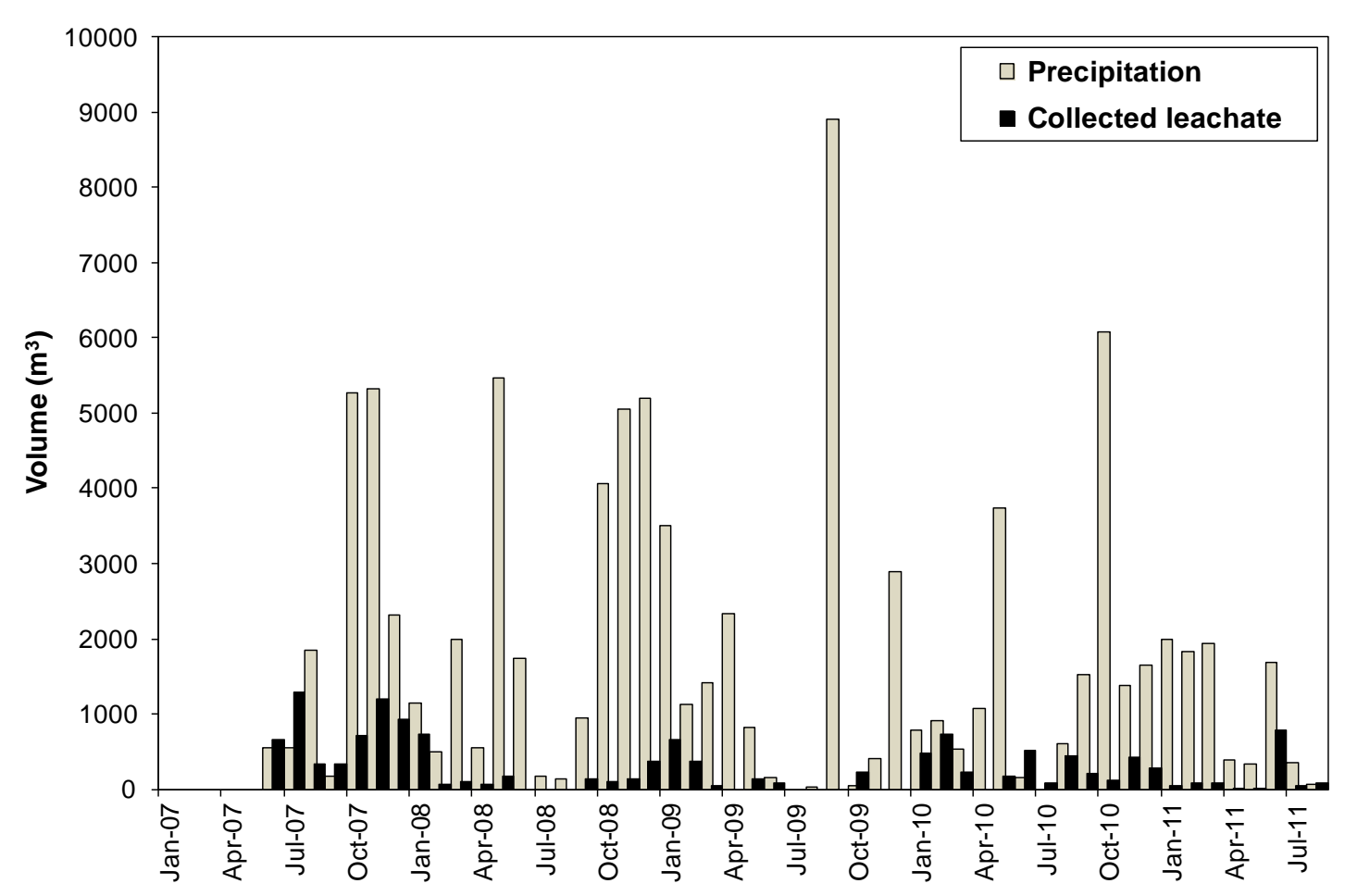

Figure 2. Precipitation and collected leachate during the studied period 

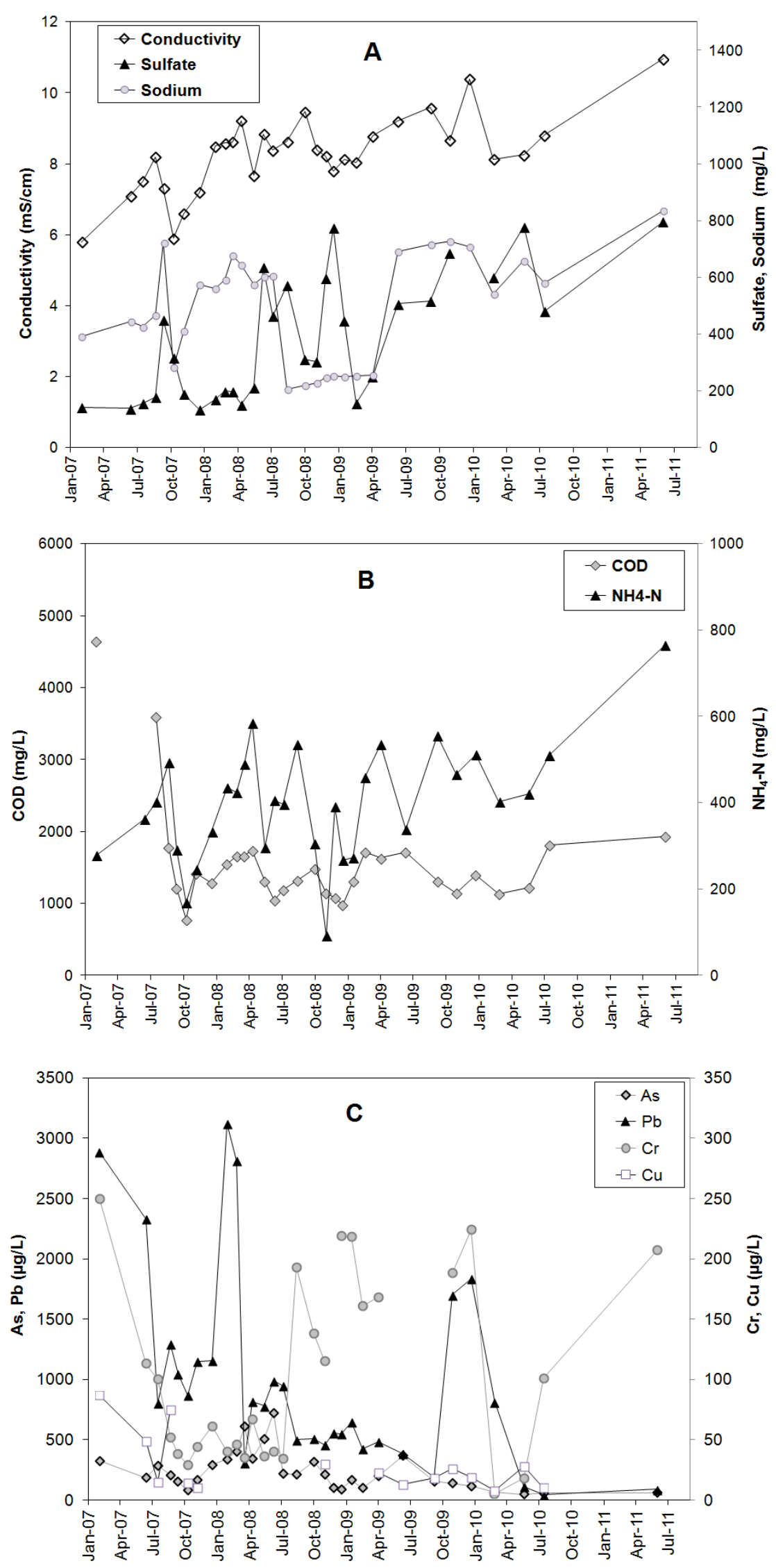

Figure 3. Pollutant concentrations in the leachate 

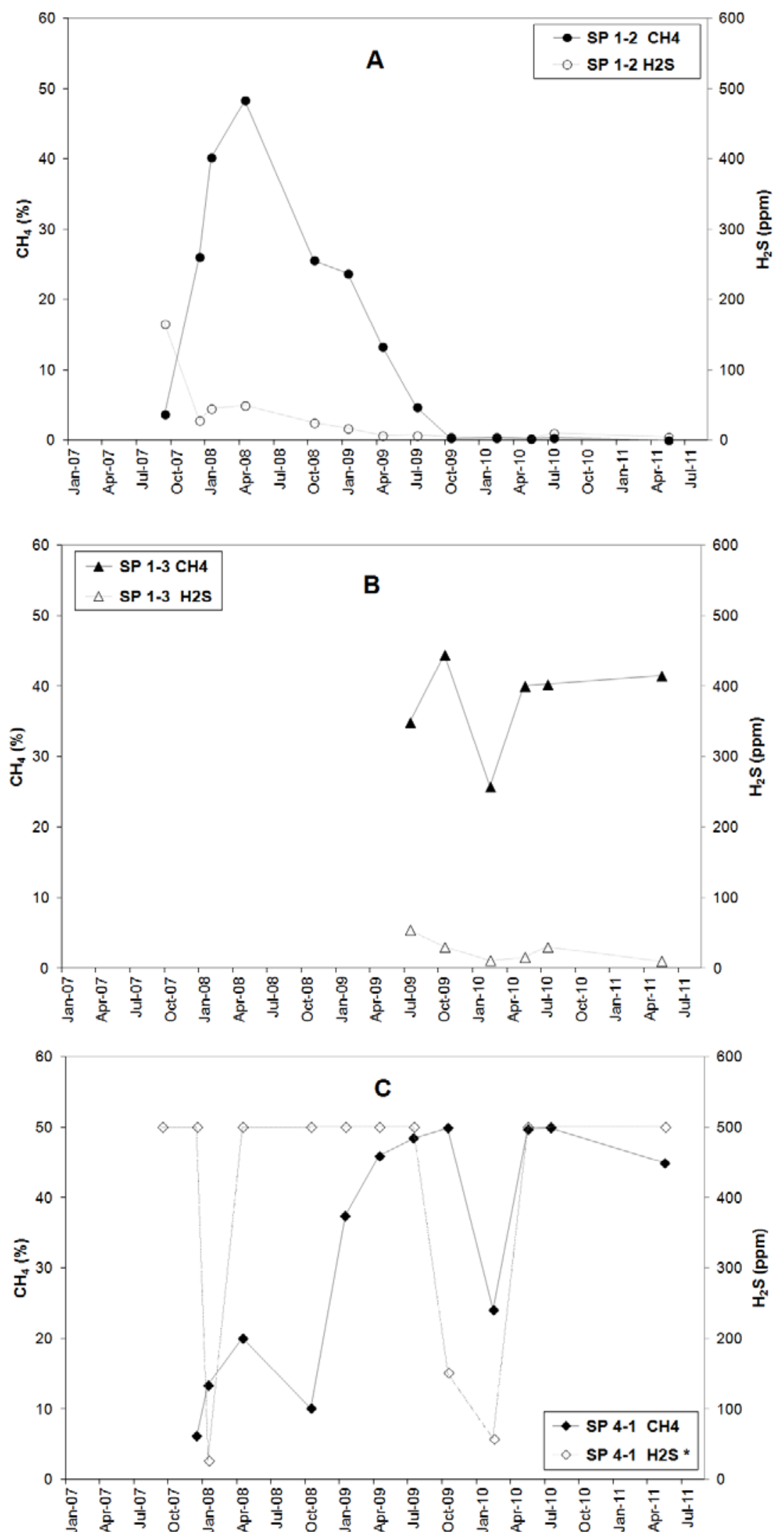

* values presented as 500 ppm correspond to out of range readings (GA2000 range: 0-500 ppm)

Figure 4. $\mathrm{CH}_{4}$ and $\mathrm{H}_{2} \mathrm{~S}$ in the sampling ports inside the landfill 


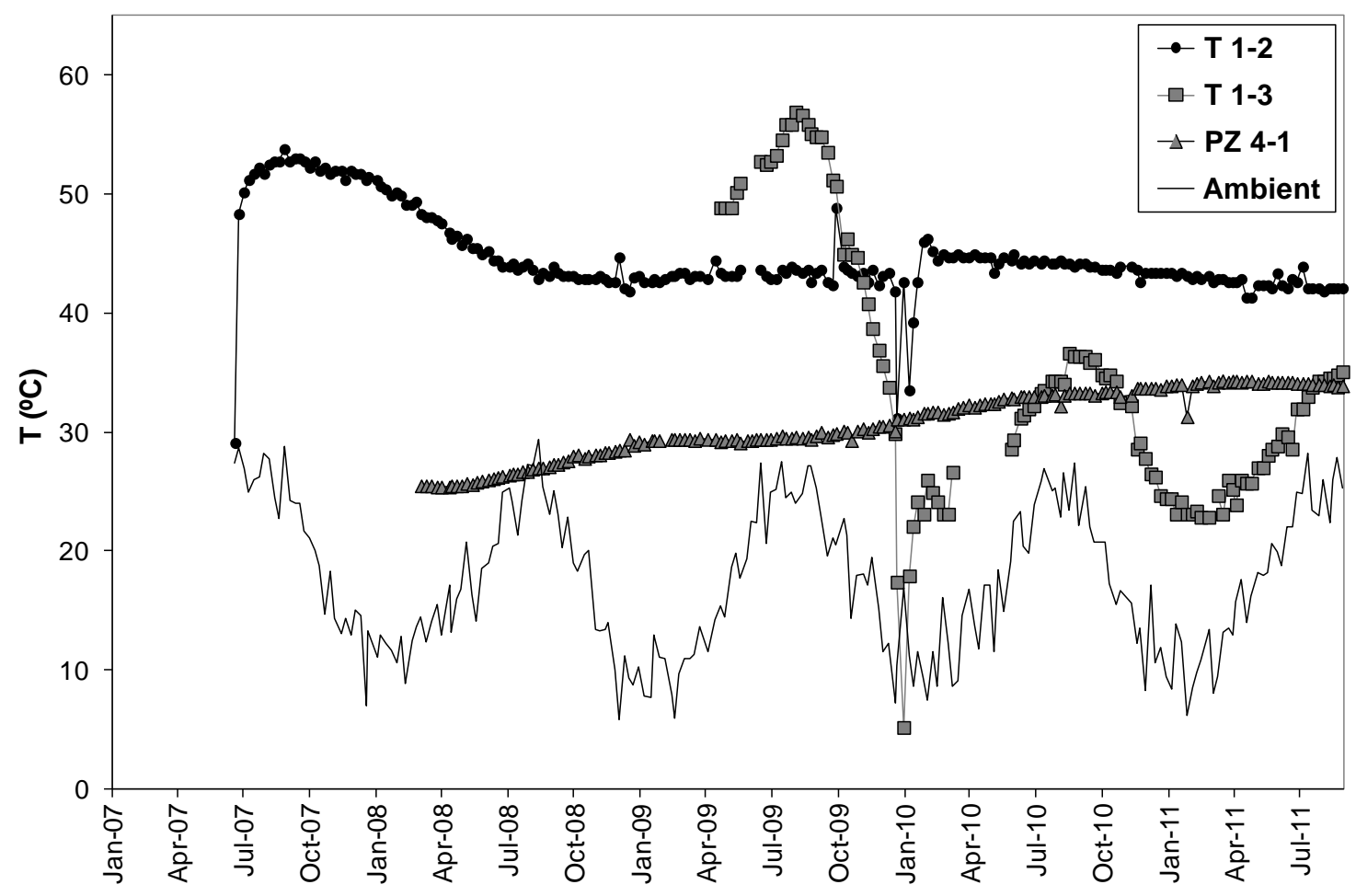

Figure 5. Temperatures inside the landfill during the studied period 
Table 1. Material dumped in the studied landfill.

\begin{tabular}{|c|c|c|}
\hline Material & $\begin{array}{c}\text { Total weight } \\
\text { (T) }\end{array}$ & $\%$ by weight \\
\hline Aggregates & 85,041 & 28.0 \\
\hline Inert building materials (bricks, concrete, stones) & 15,309 & 5.0 \\
\hline Fine inert fraction & 44,177 & 14.5 \\
\hline Ferric metal & 6,124 & 2.0 \\
\hline Non ferric metal & 1,093 & 0.4 \\
\hline Glass & 1,531 & 0.5 \\
\hline Gypsum & 219 & 0.1 \\
\hline Ceramics o porcelain & 437 & 0.1 \\
\hline Cardboard & 13,559 & 4.5 \\
\hline Plastic & 20,339 & 6.7 \\
\hline Rubber & 1,968 & 0.6 \\
\hline Wood & 95,571 & 31.5 \\
\hline Textile & 13,559 & 4.5 \\
\hline Wire & 1,312 & 0.4 \\
\hline Expanded polystyrene and foam & 3,499 & 1.2 \\
\hline TOTAL & 303,738 & 100.0 \\
\hline
\end{tabular}


Table 2. Leachate quality results versus published literature values

\begin{tabular}{|c|c|c|c|c|c|c|}
\hline Parameter & Units & Studied landfill ${ }^{a_{*}}$ & USEPA, 1995 & $\underset{\mathrm{C}_{*}}{\operatorname{Melendez}}, 1996$ & $\begin{array}{l}\text { Townsend et al., } \\
2000 \text { and Weber } \\
\text { et al., } 2002^{d_{*}}\end{array}$ & $\begin{array}{l}\text { Wang et } \\
\text { al., } 2012^{\text {e }}\end{array}$ \\
\hline $\mathrm{pH}$ & & $6.8-8.3(7.5)$ & $6.2-8$ & $4.45-8(6.95)$ & $6.1-7.9(6.90)$ & $\begin{array}{c}6.1-6.9 \\
(6.4)\end{array}$ \\
\hline DO & $\mathrm{mg} / \mathrm{L}$ & $0,3-2.1(1.0)$ & & & $0.06-1.58(0.5)$ & \\
\hline Conductivity & $\mathrm{mS} / \mathrm{cm}$ & $5.8-11(8.3)$ & & $(1.67)$ & $1.1-3.1$ & \\
\hline ORP & $\mathrm{mV}$ & $-407 / 392(-89)$ & & & $<-200$ & \\
\hline Total COD & $\mathrm{mg} / \mathrm{L}$ & $775-4,641(1,571)$ & 11,200 & $11,200(755)$ & $115-700$ & \\
\hline Dissolved COD & $\mathrm{mg} / \mathrm{L}$ & $586-4,190(1,407)$ & & & & \\
\hline Total $\mathrm{BOD}_{5}$ & $\mathrm{mg} / \mathrm{L}$ & $70-500(227)$ & 320 & $920(87)$ & & \\
\hline Dissolved $\mathrm{BOD}_{5}$ & $\mathrm{mg} / \mathrm{L}$ & $20-150(99)$ & & & & \\
\hline Dissolved TOC & $\mathrm{mg} / \mathrm{L}$ & $120-1,185(404)$ & 1,080 & $2,100(307)$ & & \\
\hline Alkalinity & $\begin{array}{c}\mathrm{mg} \\
\mathrm{CaCO}_{3} / \mathrm{L}\end{array}$ & $1,800-4,170(3,189)$ & 6,520 & $\begin{array}{l}938.2-6,520 \\
(965)\end{array}$ & $210-960(530)$ & $75-725$ \\
\hline $\begin{array}{l}\mathrm{NH}_{4}-\mathrm{N} \\
\text { Dissolved TN }\end{array}$ & $\begin{array}{l}\mathrm{mg} / \mathrm{L} \\
\mathrm{mg} / \mathrm{L}\end{array}$ & $\begin{array}{c}92-765(401) \\
182-844(463)\end{array}$ & 305 & $305(13)$ & $<1-4.1$ & \\
\hline Sulfates & $\mathrm{mg} / \mathrm{L}$ & $133-1,038$ (405) & 2,700 & $\begin{array}{c}11.7-1,700 \\
(254)\end{array}$ & $310-1,370(880)$ & \\
\hline TS & $\mathrm{mg} / \mathrm{L}$ & $3,756-5,776(4,939)$ & & & & \\
\hline TDS & $\mathrm{mg} / \mathrm{L}$ & $3,412-5,765(4,860)$ & 8,400 & $\begin{array}{c}990-8,400 \\
(2,263)\end{array}$ & $\begin{array}{c}970-3,310 \\
(2,120)\end{array}$ & $\begin{array}{l}873- \\
2,010\end{array}$ \\
\hline $\begin{array}{l}\text { TVS } \\
\text { VSS }\end{array}$ & $\begin{array}{l}\mathrm{mg} / \mathrm{L} \\
\mathrm{mg} / \mathrm{L}\end{array}$ & $\begin{array}{c}1,208-2,472(1,619) \\
5-781(75)\end{array}$ & $\begin{array}{c}170-380 \\
43,000\end{array}$ & & & \\
\hline Calcium & $\mathrm{mg} / \mathrm{L}$ & $28-608(150)$ & 600 & $90-600(270)$ & $225-690(470)$ & 274 \\
\hline Sodium & $\mathrm{mg} / \mathrm{L}$ & 206-834 (495) & 1,510 & $11-1,290(163)$ & $18.8-100.3(42.8)$ & $21-37$ \\
\hline Chromium & $\mu \mathrm{g} / \mathrm{L}$ & $5-250(105)$ & 250 & 250 & $6-74.9(17.8)$ & \\
\hline Cadmium & $\mu \mathrm{g} / \mathrm{L}$ & $<2-182(27)$ & 2,050 & $2,050(31.9)$ & ND & \\
\hline Copper & $\mu \mathrm{g} / \mathrm{L}$ & $<1-87(28)$ & 620 & $5-620(20.3)$ & $5.6-1,740(92)$ & \\
\hline Zinc & $\mu \mathrm{g} / \mathrm{L}$ & $21-735(276)$ & 8,630 & $8,630(657)$ & $\begin{array}{c}<100-1,731 \\
(433)\end{array}$ & \\
\hline Lead & $\mu g / L$ & $43-3,119$ (987) & 2,130 & $4.9-2,130(8.8)$ & $<1-14.1(4.1)$ & \\
\hline Nickel & $\mu \mathrm{g} / \mathrm{L}$ & $<3-152(59)$ & 170 & $30-170(20)$ & ND & \\
\hline Arsenic & $\mu \mathrm{q} / \mathrm{L}$ & $48-724$ (233) & 120 & $1.4-77.3(12.3)$ & $<10-148(43.8)$ & $<4$ \\
\hline Mercury & $\mu \mathrm{g} / \mathrm{L}$ & $<2-4.3(1.4)$ & 9 & 9 & ND & \\
\hline
\end{tabular}

a Concentration ranges in the studied landfill.

Full-scale study.

c Full-scale study. Concentration ranges from literature review of C\&D leachate.

d Field-cell average

e Lab-scale C\&D lysimeter study.

* Values in parentheses indicate the average value found for each parameter 
